\title{
Organizational Maturity in Companies in Terms of Strategic Directions: Cases of ONEE, ONEP and Barid Al Maghrib
}

\author{
Fatima-Zahra Mahir ${ }^{1}$, Omar Rajâa ${ }^{1}$ \\ ${ }^{1}$ National School of Commerce and management, university Ibn Zohr, Agadir, Morocco \\ Correspondence: Fatima-Zahra Mahir, PhD Student in Science and Management techniques, National School of \\ Commerce and management, university Ibn Zohr, Agadir, Morocco.
}

Received: November 5, 2017

Accepted: November 27, 2017

Online Published: November 28, 2017

doi:10.11114/bms.v3i4.2762

URL: https://doi.org/10.11114/bms.v3i4.2762

\begin{abstract}
In an environment characterized by globalization, several companies and groups are feeling increasing pressure on their competitiveness, innovation, market flexibility.... At the level of strategic management of the company and its operations, this pressure inevitably challenge the strategic direction put in place by the companies.

The present study, based on survey data collected from 3 Moroccan groups, ONEE (National office of Electricity and drinking water), ONEP (National office of Drinking Water) and Morocco Post Group (Barid Al Maghrib), aims at a more in-depth understanding of the strategic direction. A concept that has been apprehended, mainly, by two approaches:

- The comparative approach defined, in eight dimensions according to Venkatraman (1989) and Chan and al. (1997).

- The recognized typological approach of Miles and Snow (1978) which includes defenders, analyzers and prospectors.

The main objective of this research is first to analyze a literary review of these two approaches, then to project the different dimensions and theoretical characteristics on the empirical level.

On the basis of questionnaires relating to the two approaches, we identified the main dimensions that characterizes each group, classified the groups according to their typologies, and we obtained as a result two groups as type "defender" and a group as type "Analyzer".
\end{abstract}

Keywords: strategic management, strategic orientation, comparative approach, typological approach.

\section{Introduction}

Business strategy is a concept that has aroused the interest of researchers, as well as that of practitioners. Indeed, the enthusiasm of authors for the strategy has essentially resulted in the multiplication of the work and the development of a multitude of definitions. Thus, according to Porter (1980), the business strategy creates a competitive advantage for the company. Whereas according to Hambrick ${ }^{1}(1983)$, it is considered as a "model in a flow of decisions which: (a) guides the alignment of the Organization with its environment and (b) determines internal policy and procedures". In addition, according to Ward and Griffiths (1996, quoted in Bergeron, Raymond and Rivard, 2004), the business strategy is described as "an integrated set of actions to increase the Organization's long term strength and prosperity against its Competitors".

In general, business strategy is a form of response on the part of the company to its environment. Thus, strategic direction is often defined in the literature as a critical element for the success or failure of an organization. According to (Varraut, 1998), the strategic intention arises from an ambitious vision of the future and combines the necessary means to achieve one or more envisaged goals.

In addition, (Cadet, Chandra, \&Foliot, 2008), strategic intention is the strategic behaviour that results from an ambitious vision in the face of an unstable environment characterized by two aspects: increased competitive intensity as well as Unpredictable and unintelligible behaviour.

\footnotetext{
${ }^{1}$ Karim Ben Hamouda. (2006). Alignement du développement des affaires électroniques et de la stratégie d'affaires dans les PME manufacturières: impact sur la performance Organisationnelle. Université du Québec à trois-rivières.p 46.
} 
The traditional strategic models based on adaptation and position is no longer compatible with this new context. The strategies which focused on intent and movement are then the most appropriate for a totally open environment.

\section{Study Framework and Problematic}

Today, companies are increasingly confronted to high competitiveness in their business environment because of globalization (market opening, intensified competition, technological growth, etc.), which Often push for aggressive strategy, with the aim of increasing their competitiveness through the constant search for new products and markets as well as the development of technological leadership (Raymond and al 2005) to survive and grow. Some will do so by betting on the offer of a product at the lowest price, while others opt for the supply of highly specialized products or high technological content. These are very different strategies and they involve different ways of managing them.

As this issue is very complex to solve, specialists have studied the different characteristics and problems that relate to the strategic directions or intentions of the companies. Thus, two distinct approaches ${ }^{2}$ were used in the context of business strategy research: the Process and content (Sabherwal and Chan, 2001). The purpose of the process is to detect how organizations develop and implement the strategy (the How). On the other hand, the content perspective is to determine the business strategy pursued by the company (the what). In our study, we focus more on the content, in other words, on the strategies carried out rather than the desired strategies.

This is what leads us to formulate the research problem, in the form of the following question: "Strategic direction in Moroccan groups: what reality?" The importance of studying this problem is that the success or failure of any organization is largely linked to the strategy adopted by the company and therefore to its strategic directions (Mintzberg 1979, Johnson and Scholes, 2000).

Thus, in response to this problem, two approaches were widely used in the measurement and analysis of strategic directions:

-The comparative approach of Venkatraman (1989) and Chan and al. (1997) which proposed separate and prespecified dimensions. In this sense, the search for Chan and al. (1997) is to identify and measure the main traits that constitute a set of characteristics that collectively describe the strategic direction.

-The typological approach of Miles and Snow (1978), this model focuses on the ability of organizations to adjust to different environmental changes and uncertainties, especially its ability to consider strategic factors internal and external to the company (Mckee, Varadarajan and Pride, 1987). Moreover, it is also the most recognized and widespread strategic classification scheme (DeSarbo, Di Benedetto, Song and Sinha, 2005).

This paper presents the main dimensions and characteristics of each approach as well as the results of the empirical study conducted among three Moroccan groups: ONEE (National Office of Electricity and drinking water), ONEP (National Office of drinking water) and Moroccan Post office group, known as Barid Al Maghrib.

\section{Comparative Approach and Typological Approach: What Differences in Strategic Direction Analysis?}

\subsection{Dimensions of the Strategic Direction Building (Comparative Approach)}

Venkatraman (1989) proposed six distinct dimensions: aggressiveness, analysis, defense, anticipation, proactivity and risk-taking. This multi-dimensional layout has been empirically validated in several previous strategic alignment studies (Bergeron, Raymond and Rivard, 2004), (Sabherwal and Chan, 2001) and (Chan and al. 1997). In this sense, the search for Chan and al. 1997 is one of the most remarkable.

\footnotetext{
${ }^{2}$ DIDIER Edoukoi. (2007). Congruence entre la stratégie de fabrication et la stratégie d'affaires : impact sur la performance des PME manufacturières Québécoises. Université du Québec à trois-rivières, Canada.p 6.
} 
Table 1. Dimensions of business strategic direction according to Venkatraman (1989), Chan and al. (1997)

\begin{tabular}{|c|c|}
\hline Aggressiveness & $\begin{array}{l}\text { This dimension reflects the posture adopted by an organization in allocating its resources at a } \\
\text { relatively faster pace than its competitors (Clark and Montgomery, 1996) and (Venkatraman, 1989). } \\
\text { It is a combative posture that aims to maintain the strategic position in order to surpass its rivals } \\
\text { (Lumpkin and Dess, 1996). }\end{array}$ \\
\hline Analysis & $\begin{array}{l}\text { This dimension refers to the tendency of the organization to look for the origin of the problems in } \\
\text { order to generate the best solutions as possible alternatives (Venkatraman, 1989). It reflects a } \\
\text { company's ability to reinforce its knowledge (1980 Bourgeois) and to put processes in place for } \\
\text { organizational learning (Cohen and Sproull 1996). }\end{array}$ \\
\hline Internal defense & $\begin{array}{l}\text { In this dimension, emphasis is placed on improving existing areas (product/market) rather than } \\
\text { developing new areas, making companies able to accumulate the capacities and competencies } \\
\text { chosen. }\end{array}$ \\
\hline External defense & The focus is on strategic alliances with customers, suppliers or distributors. \\
\hline Anticipation & $\begin{array}{l}\text { This dimension reflects the temporal considerations implemented in strategic decisions in terms of } \\
\text { the importance expressed in relation to potential change in the competitive market. This trait is } \\
\text { reflected more by the emphasis on areas such as sales forecasting, customer preferences and the } \\
\text { formal monitoring of environmental trends. }\end{array}$ \\
\hline Proactivity & $\begin{array}{l}\text { This dimension reflects the proactive behaviour in the introduction of new products and brands, in } \\
\text { advance of competition, permanent research of opportunities, experimenting with potential } \\
\text { responses to the evolution of trends in The environment. Seeking new opportunities that may be } \\
\text { related to the current line of operations and elimination of operations that are in declining stages of } \\
\text { the life cycle (Venkatraman, 1989; Miles and Snow, 1978). }\end{array}$ \\
\hline Risk-taking & $\begin{array}{l}\text { This dimension reflects the extent of the risk in resource allocation decisions as well as the choice of } \\
\text { products and markets. Companies with this strategic trait are supposed to combine entrepreneurial } \\
\text { skills with constructive risks. "Constructive risk-taking" is seen as an important factor in stimulating } \\
\text { the entrepreneurial spirit of the company (Baird and Thomas, 1990). }\end{array}$ \\
\hline Innovation & $\begin{array}{l}\text { The emphasis is on the innovative nature of the company in the development of new products or new } \\
\text { solutions through experimentation and creativity. }\end{array}$ \\
\hline
\end{tabular}

Although Chan and al. (1997) support the theoretical construction demonstrated by Vankatraman in the theoretical construction of STROBE (The Strategic Orientation of Business Enterprise), they propose a minor modification ${ }^{3}$ concerning the six specified dimensions: Two dimensions have been added by dissociating the defense dimension into two perspectives, internal and external, and adding the dimension of innovation.

\subsection{Strategic Direction According to the Typological Approach}

Miles and Snow's typological model promotes a better understanding of the Organization's strategic reality (Christian, Bergeron, and Raymond, 2000). According to the literature in strategic management, the typology of Miles and Snow is considered one of the most popular typologies (Zahra and Pearce, 1990) and robust ${ }^{4}$ (Hambrick, Matthew, Khalifah and Yusuf, 2003) describing the strategic behaviour of companies, in the face of environmental turbulence.

This model is based on three major issues:

- The entrepreneurial problem, which is solved by making choices about products and markets;

- Engineering issues, which are solved by making appropriate technology choices to adequately meet market needs;

- The administrative problem, which is solved by making choices about the structures to be put in place to ensure the coordination of business and production activities.

This approach identifies companies as "defender", "prospector" and "analyst". Each type of strategic orientation has well-defined dominant traits.

Defenders: The companies that follow the "advocate" strategy are those who operate on a restricted field of activity and seek to improve the performance of their current activities". Generally, defender-type companies try to offer a limited line of products for a narrow segment of the market, which proves to be the most profitable. In fact, proponents do not tend to seek new product/market opportunities outside of their field of activity and are less interested in innovation than prospectors (Natcon, Mokwa and Varadarajan, 1990) (Snow and Hrebiniak, 1980).

Prospectors: Against the proponents, prospectors are innovative organizations that try to expand their field of activity by

${ }^{3}$ Larbi Safaa. (2012). Impact de la maturité de l'alignement entre l'orientation stratégique et les capacités dynamiques internet sur la performance organisationnelle : le cas du secteur hôtelier au Maroc. École Doctorale: Droit Économie Gestion Environnement Société et Territoires, université d'Angers.p 43.

${ }^{4}$ Hachemi Jarraya. (2005). Antécédents entrepreneuriaux de l'orientation stratégique des PME manufacturières. Université du Québec à trois-rivières, Canada.p 13. 
continually seeking new opportunities by developing and manufacturing new products tailored to the needs of their customers. Thus, according to Miles and Snow (1978.2003), prospectors are real creators of change in their market, as they try to be the first to penetrate certain markets and to promote innovation by a high level of expertise (Side and Malo, 2002).

Analysts: The analyzers are hybrid or intermediate type companies (Miles and Snow, 1978). Indeed, they share both the strengths of the defenders and the prospectors. By combining the characteristics of the two typologies, the analysts simultaneously seek to minimize the risk, while maximizing opportunities to ensure better growth. Thus, they try to maintain a stable domain through a limited number of product lines, while trying to prospect a limited number of attractive new markets. Analysers rarely make changes in their products and/or markets compared to prospectors (Hambrick, 1983). On the other hand, they try to imitate the defenders by offering good quality products with low prices.

The table 2 presents Miles and Snow's typological approach according to prospectors, defenders and analysts through their main features or problems.

Table 2. Key features of Miles and Snow strategic profiles ${ }^{5}$

\begin{tabular}{|c|c|c|c|}
\hline & Prospectors & Analyzers & Defenders \\
\hline $\begin{array}{l}\text { Entrepreneurial } \\
\text { issues }\end{array}$ & $\begin{array}{l}\text { - Growth through product and } \\
\text { market development. } \\
\text { - Focus on innovation. } \\
\text {-Expanded and continuously } \\
\text { developing market. } \\
\text {-Expanded strategic } \\
\text { intelligence (opportunities). }\end{array}$ & $\begin{array}{l}\text { - Several products and markets, } \\
\text { stable and variable. } \\
\text { - Targeted strategic monitoring } \\
\text { (marketing and R\&D). } \\
\text { - Sustained growth through } \\
\text { market penetration and } \\
\text { exploitation of new } \\
\text { opportunities. }\end{array}$ & $\begin{array}{l}\text { - Product development } \\
\text { limited to existing products } \\
\text { - Narrow and well targeted } \\
\text { market Segment. } \\
\text { - Cautious and gradual } \\
\text { growth through greater } \\
\text { penetration of the targeted } \\
\text { market. } \\
\text { - Targeted strategic } \\
\text { monitoring (efficiency and } \\
\text { productivity). }\end{array}$ \\
\hline $\begin{array}{l}\text { Engineering } \\
\text { issues }\end{array}$ & $\begin{array}{l}\text { - Use of different } \\
\text { technologies as needed. } \\
\text { - Low degree of routinisation } \\
\text { and mechanization. } \\
\text {-Technology anchored to } \\
\text { knowledge and skills. }\end{array}$ & $\begin{array}{l}\text {-Dual technology, with stable } \\
\text { and flexible components. } \\
\text {-Moderate technological } \\
\text { efficiency. }\end{array}$ & $\begin{array}{l}\text { - Use of only one primary } \\
\text { technology. } \\
\text {-Investment in technology } \\
\text { management to improve } \\
\text { efficiency. }\end{array}$ \\
\hline $\begin{array}{l}\text { Administrative } \\
\text { issues }\end{array}$ & $\begin{array}{l}\text {-Simple Structure (divisional } \\
\text { trend). } \\
\text {-Decentralized management } \\
\text { with horizontal information } \\
\text { sharing. } \\
\text {-Teamwork (by project). } \\
\text { - Marketing and } \\
\text { R\&D-based rewards system. }\end{array}$ & $\begin{array}{l}\text { - Matrix Structure. } \\
\text {-Vertical and horizontal sharing } \\
\text { of information. } \\
\text { - Marketing and } \\
\text { engineering-based rewards } \\
\text { system. }\end{array}$ & $\begin{array}{l}\text { - Simple Structure } \\
\text { (functional trend) organized } \\
\text { around production and } \\
\text { control. } \\
\text {-Centralized management } \\
\text { with vertical sharing of } \\
\text { information. } \\
\text { - Standardized processes. } \\
\text {-Production and } \\
\text { finance-based rewards } \\
\text { system. }\end{array}$ \\
\hline
\end{tabular}

The typology of Miles and Snow is considered as an important typology; it reflects a complex set of attributes and issues affecting market, technology and structure. By giving rise to three forms or types of organization, called Strategic types : defensive, prospective and analytical.

What also characterizes the typological approach is that it is rooted in a set of conceptual classification criteria, where each type of business strategy is considered to have a common strategic direction with a set of characteristics.

Finally, the typology of Miles and Snow has been validated and used in several empirical studies and has been recognized to provide a greater understanding of the Organization's strategic reality.

\section{Presentation of the Research Methodology}

In order to study and analyze the strategic direction of groups, a questionnaire was conceived and administered to three Moroccan groups (ONEE, ONEP and Post Morocco). The choice of these groups is justified by the common points that characterize our sample:

- They are Moroccan groups.

${ }^{5}$ Claire V. de la Durantaye. (2012). Stratégie et pratiques d'affaires: Un alignement qui conduit à la performance. INFOPME $\mathrm{N}^{\circ} 12 . \mathrm{p} 8$. 
- They have been around for a long time.

- They are all, thanks to their fields of activity, pillars of Moroccan economy.

As a part of a descriptive approach, we have developed a crude picture of the situation according to the theoretical models whose data are processed using the SPSS (statistical Package for Social the Science) software.

For example, two-time questionnaires were conducted in Q1 and Q2, the two questionnaires are as follows:

-The first questionnaire deals with the eight dimensions of the comparative approach. The questions are presented on a scale which gives us an idea about the importance of each criterion.

-The second concerns are different characteristics of each strategic profile, where respondents had to classify their groups according to the typology of Miles and Snow by determining which of the three descriptions (referring to the definitions of each of the Miles and Snow Strategies) was the most appropriate for their organization.

Since our study focuses on strategic direction, and to be consistent with the subject of the research, all respondents belong to the Directorate-General and have positions of responsibility (division head, engineers,...) enabling them to have all the information concerning the intention, the vision and the orientation of their groups.

\section{The Study Results in Both Approaches}

Before presenting the results of our survey, we briefly present our groups, ONEE and ONEP, which are Moroccan public establishments of an industrial and commercial character with civil personality and financial autonomy. Morocco Post Office is a postal operator and provider of Moroccan financial services.

\subsection{Based on the Comparative Approach}

- Market share: The ONEE and the ONEP occupy a very good market share.

- Problem origin analysis: the position of problem origin analysis, especially the problems related to loss are extremely important in ONEE. This analysis is through conducting studies and investigations with the aim of the detecting the main causes and sources. This it is extremely important in the ONEP to ensure a 24-hours customer service hotline as well as for Barid Al-Maghrib.

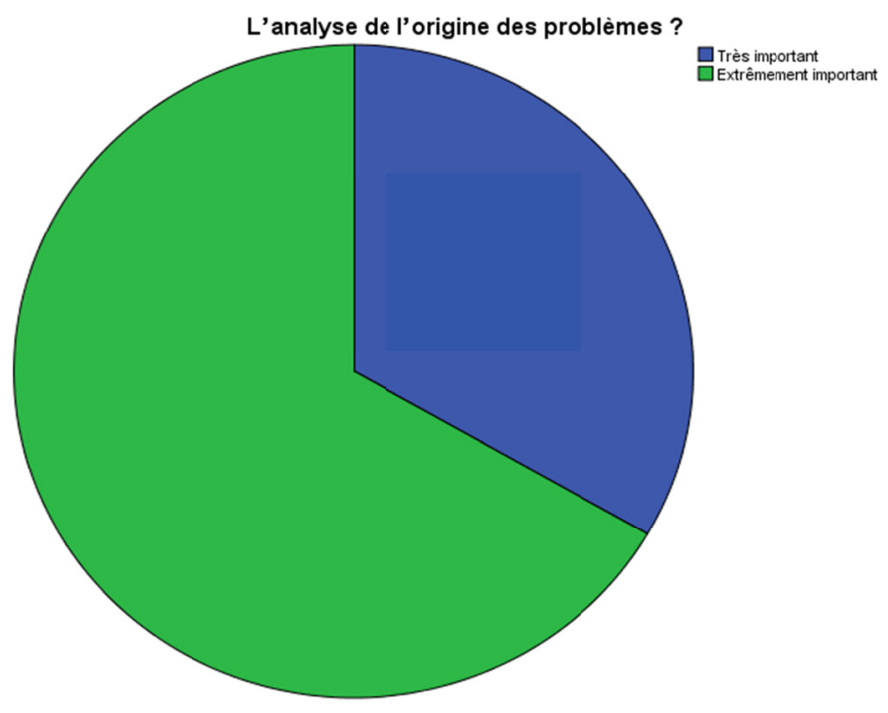

-to maintain their market share, and in order to improve the quality of their services, the ONEE and the ONEP place a great deal of importance on existing products and services by good quality, time, price control, and the improvement of the processes of Production .... For example, the ONEE, in the event of a breakout, the officials must present to the central management a report in which they justify and explain in a detailed way the causes of this discrepancy. The improvement of production processes is also seen as an important dimension in ONEE by following trends and by addressing the challenges of sustainable development as much as possible, such as the integration of renewable energies into resources. 


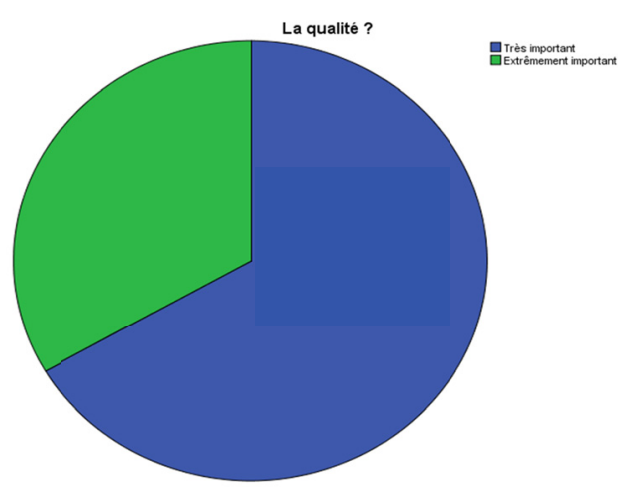

-Barid Al-Maghrib also attaches great importance to existing products and services by good: quality, delay, and the improvement of production processes.... As for the control of prices which occupies a slightly important position.

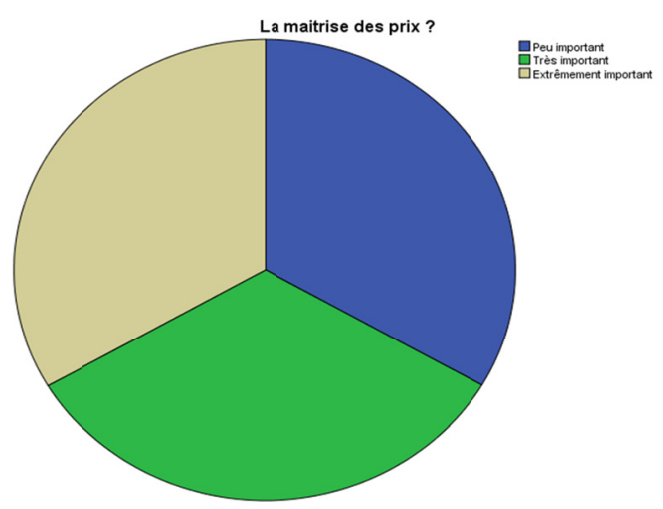

-The position of the new products is small in the ONEE and it is not at all important for the ONEP.

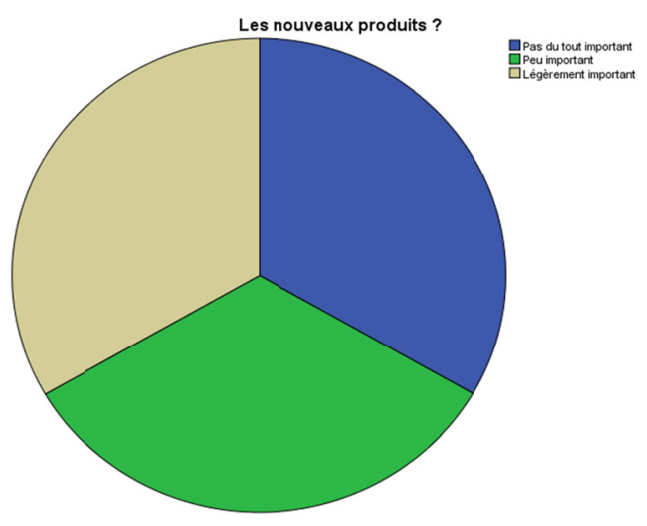

-The search for opportunities in relation to new products is rarely done in ONEE and ONEP; this is quite normal since they focus on a single sector of activity. On the other hand, it is fairly regular at Barid Al-Maghrib.

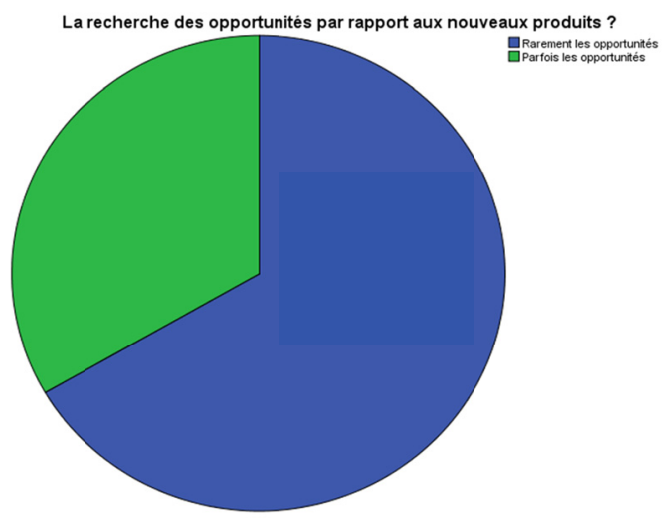




\subsection{According to the Typological Approach}

The typological approach results are characterized by three major problems. ONEE and ONEP belong to the strategic "defender" profile, whereas Barid Al-Maghrib belongs to the "Analyst" profile. This typology is justified on the basis of answers which are presented as follows:

-In response to the entrepreneurial problem, the "defender" type groups such as the case of the ONEE \& the ONEP target a well-defined and relatively stable market that strive to control with an aggressive offer of competitively priced products and an excellent Customer service. These groups need to isolate themselves from changes as much as possible in a sector where it is difficult for competitors to penetrate. Barid al-Maghrib as an "Analyst" type group has basic products: mail-messaging \& Logistics, but it also develops other new products and services such as digital post, Al Barid Bank, the Financial services ... etc. Thus, it chooses to exploit new markets while seeking to preserve traditional base of customers.

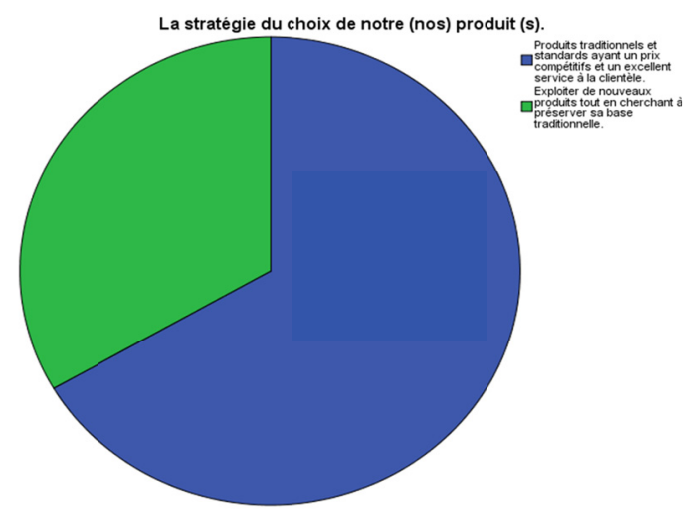

- With a conservative-type strategy, 'Defenders' primarily focus on improving production processes and look for productivity.

-In response to the engineering problem, the three groups require a high level of control for technology which they develop and strive to use at full capacity.

-In response to the administrative problems, the defenders apply a centralised structure whose most developed functions are those of production and control. For the analyst group, "Barid Al-Maghrib" opts for a structure that facilitates operations for commodities and new products.

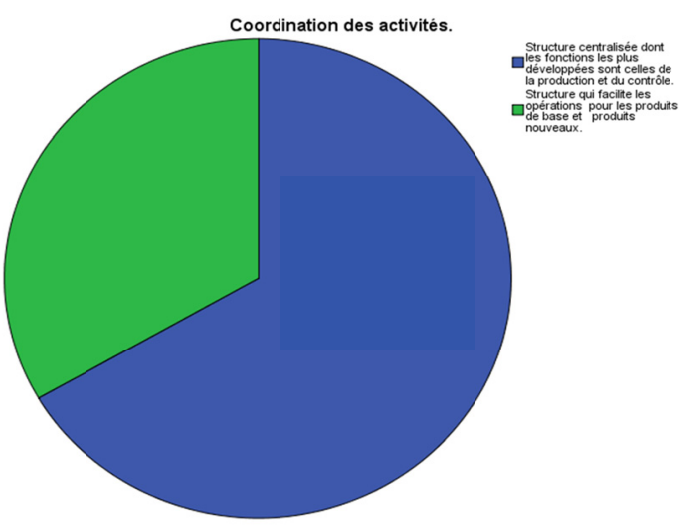

\section{Discussion}

The ONEE is considered a pillar of energy strategy in the electricity sector in Morocco with the aim of:

-Generalizing electricity access.

-Modernizing and expanding networks for production, marketing and distribution of electrical and hydraulic resources.

-Satisfying electricity demand in the best conditions, cost and quality of service.

-Fighting against supply loss and implementing new electricity-saving instruments and techniques....Thus, the electricity industry is increasingly striving to guarantee the country's supply of energy.

The ONEP is also considered as a group within a vital sector in Morocco:

-The office focuses on water with more than $85 \%$ of the national production of drinking water covering the needs of $96 \%$ 
of the total urban population of the kingdom;

-The Office has adopted a strategy focusing particularly on securing the country's supply of drinking water with best conditions, cost, quality of service, diversification of production sources, control of demand, generalized access to drinking water, active intervention in liquid sanitation and environment preservation.

Barid Al-Maghrib is looking for a certain balance in solutions they conceive to respond to various problems. This analyst group is seriously studying its market to minimize risks, while seizing certain growth opportunities rather than developing totally new products or services. So, they bring interesting improvements to existing products.

Table 3 presents the main features and synthesis of profiles that have been studied, with examples:

- Defenders: ONEE \& ONEP.

- Analyst: Morocco Post Office.

Table 3. Synthesis of the profiles studied

\begin{tabular}{|c|c|c|}
\hline $\begin{array}{l}\text { Profile } \\
\text { Problematic }\end{array}$ & Defender Profile : ONEE \& ONEP. & Analyst profile : Morocco Post Office \\
\hline $\begin{array}{l}\text { Entrepreneurial } \\
\text { problem }\end{array}$ & $\begin{array}{l}\text { Traditional products and a well targeted } \\
\text { market } \\
\text { The ONEE is an office that produces } \\
\text { electricity, thus it is the company that submits } \\
\text { applications to this office. } \\
\text { The ONEP is a national producer of drinking } \\
\text { water with more than } 85 \% \text { of the national } \\
\text { drinking water production, more than } 1 \text { billion } \\
\text { m3 per year. In addition, it is a supplier of } \\
\text { drinking water in rural areas with an access } \\
\text { rate of } 95 \% \text {. }\end{array}$ & $\begin{array}{l}\text { Exploit new products and markets while seeking to } \\
\text { preserve the traditional base. } \\
\text { Morocco Post Office basic products are Mail-messaging } \\
\text { \& logistics But it seized the opportunity to develop other } \\
\text { new products and services such as Digital post, Al Barid } \\
\text { Bank, financial services ... etc. For example, the digital } \\
\text { post is considered by Morocco Post Office as a trade that } \\
\text { was developed to save the post service. }\end{array}$ \\
\hline $\begin{array}{l}\text { Engineering } \\
\text { problem }\end{array}$ & $\begin{array}{l}\text { Control of technology to improve } \\
\text { efficiency. } \\
\text { The ONEE is based on a technology that is } \\
\text { perfectly proficient. In addition, before using } \\
\text { or working with any technology, the user must } \\
\text { first have an authorization to certify that he } \\
\text { has mastered this technology. }\end{array}$ & $\begin{array}{l}\text { Control of technology to improve efficiency. } \\
\text { Following the various traditional and new products and } \\
\text { services of Barid Al-Maghrid, and in order to ensure its } \\
\text { role correctly, post Morocco is to master the technology it } \\
\text { uses. }\end{array}$ \\
\hline $\begin{array}{l}\text { Administrative } \\
\text { problem }\end{array}$ & $\begin{array}{l}\text { Centralized Structure. } \\
\text { There are decisions concerning the agencies } \\
\text { of ONEE where officials of have the } \\
\text { autonomy to decide, but generally the major } \\
\text { decisions (for example those relating to the } \\
\text { budget) are taken at the higher level (the } \\
\text { management Regional headquarters). }\end{array}$ & $\begin{array}{l}\text { Structure that facilitates operations for commodities } \\
\text { and new products. } \\
\text { Morocco Post Office has a structure composed of three } \\
\text { levels (local level, regional level and central level). } \\
\text { Information or production is located at the local level, the } \\
\text { agency level, but interactions and management are done in } \\
\text { a way that facilitates operations between the three levels. }\end{array}$ \\
\hline
\end{tabular}

From this summary table, we see companies that opt for a defender strategy can prove to be active competitors. However, these companies are vulnerable to changes that occur in the environment, therefore are not well positioned to make use of the new opportunities that might arise. While companies opting for analyst strategy, they manage to pull their pin from the game in front of their competitors thanks to the equilibrium position they choose. But if they happen to lose that balance, they may find it difficult to recover.

\section{Conclusion}

As a conclusion, we could say that the strategic direction of a firm is crucial to its performance. In fact, regardless of the strategy adopted, the company is trying to gain a competitive advantage that would result in growth in sales, profits or productivity.

This survey allowed us to provide an idea of the main characteristics of each strategic profile:

- Generally, defender type companies try to define and conserve niches in relatively stable and restricted areas of activity, where competitors are having difficulty of access. In addition, they carefully study all aspects of a strategic decision in order to ensure that the latter is the most appropriate. Thus, these companies face competition by emphasizing the superiority of quality of products and services offered and also by offering better delays, etc. In addition, the defenders focus on operational efficiency and cost control to maintain their competitive advantage.

- Unlike the defenders, the analysers strive to ensure the balance between efficiency and innovation. Through the diversification of their fields of activity, the analysers must engage in multiple planning processes and very formal evaluation of new products or new market opportunities. It is in fact a category of hybrid companies adopting "defender" behaviour in certain circumstances and in others, "prospective" behaviour. 
Of course, the three organizations are national pillars of Morocco, but they don't escape competition:

- Several officials operating in electricity and renewable energies confirm that Morocco is opening up to competition from the market for production and selling the electricity produced from renewable energy. Thus, the new legislative and regulatory framework, relating to the law 13-09 on renewable energies, marked the new energy strategy and gave for the first time in the history of energy in Morocco the possibility for private developers and Private companies to develop renewable power generation capacity and commercialize this energy in the electric market.

- Barid Al Maghrib also, leads a strategy designed to integrate new technologies in its trades to reinforce its position of leadership while diversifying the range of its services, to respect the international standards of quality and to reconcile between its public service mission and competitive markets. For its part, the bank subsidiary Al Barid Bank, launched in June 2010 has strengthened the mission of universal service of the group. Indeed, the activity of financial services has recorded major developments revolving around the upgrading and widening of the offer ... for all Moroccans. Moreover, and compared to other banks, Al Barid Bank has the most extensive banking network with 938 own agencies, 760 postal agencies that automatically become banking agencies and 510 automated teller machines (ATMs). That is to say that the establishment has 1700 agencies covering the entire national territory, including the most remote rural areas where Barid Al-Maghrib has always ensured local benefits for citizens. And in terms of competition, Al Barid Bank is a complementary bank of other banking institutions in the country which are mainly located in urban areas, while the 938 agencies are mainly located in remote areas and isolated from the country.

\section{References}

Claire, V., \& de la Durantaye. (2012). Stratégie et pratiques d'affaires: Un alignement qui conduit à la performance. INFOPME $\mathrm{N}^{\circ} 12$.

DIDIER Edoukoi. (2007). Congruence entre la stratégie de fabrication et la stratégie d'affaires: impact sur la performance des PME manufacturières Québécoises. Université du Québec à trois-rivières, Canada.

Gosselin, M., \& Dubé, T. (2002). Influence de la stratégie sur l'adoption des mesures de performance en vigueur dans le système de comptabilité de gestion. École de comptabilité, université Laval Québec, Canada.

Hachemi, J. (2005). Antécédents entrepreneuriaux de l'orientation stratégique des PME manufacturières. Université du Québec à trois-rivières, Canada.

Jean, M. P. (2012). Tous DRH : Les meilleures pratiques par 51 professionnels », édition Eyrolles.

Jonathan, P. (2011). Évaluation de la performance de la formation en entreprise par une approche systémique. Université des sciences et technologies de Lille, institut d'administration des entreprises école doctorale SESAM, Lille.

Karim, B. H. (2006). Alignement du développement des affaires électroniques et de la stratégie d'affaires dans les PME manufacturières: impact sur la performance Organisationnelle. Université du Québec à trois-rivières.

Larbi, S. (2012). Impact de la maturité de l'alignement entre l'orientation stratégique et les capacités dynamiques internet sur la performance organisationnelle : le cas du secteur hôtelier au Maroc. École Doctorale: Droit Économie Gestion Environnement Société et Territoires, université d'Angers.

Miles, R. E., \& Snow, C. C. (1978). Organizational strategy, structure, and process, McGraw-Hill.

Porter, M. E. (1982). Choix stratégiques et concurrence: techniques d'analyse des secteurs et de la concurrence dans l'industrie. Economica.

\section{Copyrights}

Copyright for this article is retained by the author(s), with first publication rights granted to the journal.

This is an open-access article distributed under the terms and conditions of the Creative Commons Attribution license which permits unrestricted use, distribution, and reproduction in any medium, provided the original work is properly cited. 